\title{
Determinants of Raw Milk Supply and Value Addition Participation in Mecha Woreda, Amhara National Regional State, Western Ethiopia
}

\author{
Yeshiwas Tilahun Jema Haji Bosena Tegegn Simegnew Tamir
}

\begin{abstract}
Dairy sector has important role in supporting the national economy and livelihood of milk producers. Milk producers are one of key actors that play great role along the dairy value chain in the study area. Milk producers' participation in milk and milk products marketing played roles in improving household welfare, and also means improved food security and reduced poverty. Though there are studies conducted on milk production, processing and utilization, there is insufficient information on determinants of milk producers'milk supply and milk value addition participation in Mecha woreda. Thus, this study was conducted in Mecha woreda with objectives of analyzing determinants of smallholder milk producers' participation decisions and intensity in cow milk supply and value addition. Formal survey techniques were employed to collect data. The data were collected from 200 milk producers using systematic random sampling techniques. Bivariate probit model was employed for participation decisions while recursive bivariate tobit model was used to analyze determinants of participation intensities. The econometric model result revealed that age of household head, number of local cows owned, distance of dairy products market, household milk consumption, family size, dairy farm experience, milk yield size per day, and membership in dairy cooperatives were influential variables that affected milk supply participation decision significantly. The household land size, milk consumption, distance of dairy market, milk yield per day, cooperative membership and milk market experience affected milk supply participation intensity significantly. Value addition participation decision was influenced by land size, distance of market and value addition experience positively and significantly. Distance of dairy product market, dairy farm experience, and membership in dairy cooperatives influenced value addition participation intensity significantly. In this study, improving market access by increasing number of dairy cooperatives, road and infrastructures, upgrading traditional milk products, introducing labor saving technologies, and empowering cooperatives and producers are recommended to increase smallholders' participation in dairy products marketing.
\end{abstract}

Keywords: Bivariate Tobit-Probit, milk supply participation, value addition participation

DOI: $10.7176 / \mathrm{JMCR} / 65-01$

Publication date: February $29^{\text {th }} 2020$

\section{INTRODUCTION}

Dairy production is one of among agricultural sectors which have huge development opportunity in Ethiopia. The country has more than 18 million dairy animals which account 31.92 percent of the total cattle population and produces 3.1 billion liters of cow milk annually with milk yield of 1.37 litter/cow/day (CSA, 2017). Dairy production is dominantly characterized by subsistence farming systems by which about 98 percent of total milk is produced by smallholder dairy producers (TAP Consultancy Services, 2016).

Dairy sector has been recognized by Ethiopia government as it supports national economy and the livelihood of rural, peri-urban and urban milk producer households. Therefore, the dairy master plan has been prepared and eight major dairy milk shed areas have been identified in the country (Brandsma et al., 2013). The sector has been strongly interlinked with mixed cultivation by providing manure and draft power for crop sector. It also provides employment opportunities to a large number of people; and is important to flow foreign currency in. This sub-sector contributed $12-16 \%$ to the national economy GDP and shares $45 \%$ of the agricultural GDP (Behnke and Fitaweke, 2011). In addition, dairy products and by-products have large contributions to smallholder dairy producers and the country at large in ensuring food security, nutrition and income generation (Habtemariam et al., 2002). About $85 \%$ of the total milk produced is consumed at the household level and only $7 \%$ of raw milk is supplied to market in formal and informal markets and the remaining (8\%) milk is processed to butter, ghee, yogurt and soft cheese (Land O'Lakes, 2010). Despite raw milk marketing, small-holder farmers add value to milk by processing milk using indigenous knowledge. Butter, ergo (fermented whole milk), cottage cheese (ayib), and butter milk are commonly marketed dairy products (Azage et al., 2013; Alganesh and Yetenayet, 2017).

Contrary to low milk products supply, the demand for milk is increasing with rapidly increasing of population growth rate and urbanization. So that the domestic demand for dairy products is being met through imports. The country spent approximately US\$ 11-15 million in foreign exchange on imports of milk and milk products between 2011 and 2013 (FAO and NZAGGRC, 2017). To address these problems, Minister of Agriculture in Ethiopia aimed to improve cow productivity through extension services provision (improved 
technologies, building capacity, promoting collective action, and facilitating linkages) followed by the livelihood and income of smallholder dairy producers. The issues of dairy sector are planned in GTP II plan to satisfy domestic milk demand and begin to export cow milk in 2020 by improving traditional family dairy production (Shapiro et al., 2015).

Amhara National Regional State is one of the highest potential milk producer regions in Ethiopia next to Oromia Region. The Region shares about 23.1 percent of milking cows population and produces more than 597 million liters of milk per annum which contributes 19.1 percent of the national milk volume (CSA, 2017) but the amount of milk supplied to market is less than 10\% (LMD, 2013). As stated at national level, small holder milk producers engage in producing and marketing traditional milk products; butter, ghee, ayib, and metata-ayib. In Amhara Region, Mecha woreda is one of the potential milk producing areas among West Gojjam Zone's wordas. The woreda's agricultural practice is characterized by mixed farming system in which both productions are interdependent each other. There are 37,347 milking cows of which 4.8 percent are cross lactating cows and the total milk production by the woreda is estimated about 22,171,523.22 liters per year (North Mecha Woreda livestock and development office, 2019).

\subsection{Statement of the Problem}

Ethiopia has large potential of dairy production with high cows population while the sector is not fully exploited. Poor exploitation of dairy industry is brought due to poor genetic of indigenous cattle, inadequate feed resources, short supply of improved breed, weak linkages between research, extension service providers and technology users, weak promotion of dairy products market, lack of clear milk marketing system, lack of market information, lack of unique and clearly defined dairy policy and institutional structures (Zelalem et al., 2011; Bingi and Tondel, 2015; Tesfaye, 2017). Though the country has large number of milking cows, milk supply and per capita milk consumption is low. Ethiopian dairy products consumption per annum was $39 \mathrm{~kg}$ per person in 2011 while the world average consumption was approximately $90 \mathrm{~kg}$ (FAO, 2017). On the other hand the per capita milk consumption was 19 litters in 2016 (ATA, 2016). It is low compared to countries per capita liquid milk consumption; 110 litters in Kenya (Rademaker et al, 2016), 71 litter in Sudan (RVO, 2016) and 59 litter in Rwanda (Ntirenganya , 2016 ) with a few livestock population compared to Ethiopia and very far below the FAO/WHO recommended per capita milk consumption which is 200 liters (Getachew et al., 2009). One of the reasons for low consumption of milk is low supply of milk that is only $5 \%$ of the country milk produced is sold in commercial markets (CSA, 2011). Similarly below $10 \%$ of milk produced is marketed to formal channel in Amhara Region (LMD, 2013).

Value addition is another alternative means of supporting livelihood income for dairy producers by processing high perishable raw milk to less perishable milk products like butter and cheese at local market. Ethiopia has untapped potential of adding value to milk. However, the demand of processed milk products could not be addressed by existing volume of milk products available in the market. Currently the quantity of exported dairy products and its destinations are insignificant that the country is net importer. Butter was mainly exported to Djibouti and South Africa, targeting to Ethiopian Diaspora. From the south Eastern region of Ethiopia, milk is solely exported to Somalia (Getnet, 2009). Producers mainly added value to milk and produced butter, ghee and metata-ayibe that they used them as source of income, food and medicinal value (Eyassu and Asaminew, 2014). Appreciation of milk value addition participation at farm level is needed to increase producer income and support their livelihood. Countries like India appreciate indigenous milk products and undertake regular experiments to improve and commercialize those products (Chawla et al., 2008) but in Ethiopia the concern of improving of these products is very limited. Low milk quality, weak promotion of milk products, and unimproved processing technologies are among constraints of milk value addition (Frew and Getnet, 2013).

The existing milk and milk products amount of supply could not satisfy the increasing demand of milk in the country. In this regard, increasing producer's participation in milk market and level of participation has important roles in improving household welfare, and also means improved food security and reduced poverty (Mmbando et al., 2017; Poole, 2017). However, identifying and understanding factors influencing smallholder producers to participate in milk market and value addition is needed to be prior act before intervention. Numbers of studies were conducted in different regions of the country by different scholars. For instance; Berhanu et al., 2014; Benyam et al., 2016 ; Ali ,2017 conducted studies on determinants of milk market participation of smallholder farmers. Similarly Betela et al ,2017, Embaye ,2015 ; Benyam et al. ,2017 ; and Tadele et al. ,2014; identified factors that influence milk value addition participation at farm level. Yitaye et al., 2009; Shewangzaw et al., 2016 Eyassu and Asaminew , 2014 conducted research on production, processing, and utilization of cow milk in the Amhara region. Though number of researches conducted in different regions of the country by different scholars, empirical study has not been studied and documented in the particular study area. Therefore, this study was conducted to address the paucity of information on factors that influence small holder milk producers' participation and intensity in milk market and value addition in North Mecha woreda. This study is important for policy makers and dairy stakeholders to understand factors that influence producers' milk market 
and value addition participation decision and intensity in order to develop strategies required to improve small holder milk producers' participation in milk market and value addition. Thus, this study aimed specifically to analyze the determinants of milk producers' milk supply participation decision and level of participation in milk value chain; to analyze the determinants of milk producers' value addition participation decision and level of participation.

\section{METHODOLOGY}

\subsection{Description of the Study Area}

The study was conducted in North Mecha Woreda which is located $30 \mathrm{kms}$ south-west of Bahir Dar town, the capital of Amhara Region and 524 km north-west to Addis Ababa. It borders North Achefer in the north, South Achefer in the south and west, and Yilmana Densa Woreda in the east. The woreda has 35 rural kebles and 3 urban kebeles. Based on 2012 the population projection the woreda had 317, 963 population of which 160,686 and 175,277 were male and female respectively. Merawi (the town of the woreda) had 18,682 total populations of which 9,632 and 9,050 were males and females respectively (CSA, 2011). The woreda's covers 112438 hectare of land which comprises potential cultivated land( 12677.19 ha), grazing land (12818.98 ha), bush land ( $2156.6 \mathrm{ha}$ ), settlement land ( $4120.6 \mathrm{ha}$ ), natural forest (6670.98 ha), and human made forest land( $2592 \mathrm{ha})$. From the total land $94 \%$ of the land is plain and the remaining lands are hill and valley lands. The soil type of the woreda is mainly red soil which accounts $97 \%$ whereas the remaining portion of land is black soil. The Woyina Dega agro ecology of the woreda covers $95 \%$ and the remaining $5 \%$ agro ecology is characterized by Dega. The woreda annual average temperature is $24^{\circ} \mathrm{C}$ and the annual average rainfall is about $2000 \mathrm{~mm}$.

The woreda has 12 milkshed kebles that are identified based on milk production potentials and market accessibility. According to the Woreda livestock development office basic data, the woreda had 80607, 117738 , 44472,37803,44272,80488,34387,17514,7859, an 1096 oxen, cows, bulls, heifers ,calves, sheep, goats, donkeys , mules and horses respectively. The woreda had 6,570 and 114,722 cross breed dairy cattle and local breed dairy cows respectively. It had 37,347 lactating cows; of which the total breed lactating cows accounts only $4.77 \%$. The monthly estimated milk production of the woreda is 19,507,076.82 litter from local cows and 2,664,446.4 litters of milk from cross dairy cows which indicates that about $87.98 \%$ of milk is produced from local breed dairy cows (woreda livestock development office, 2019).

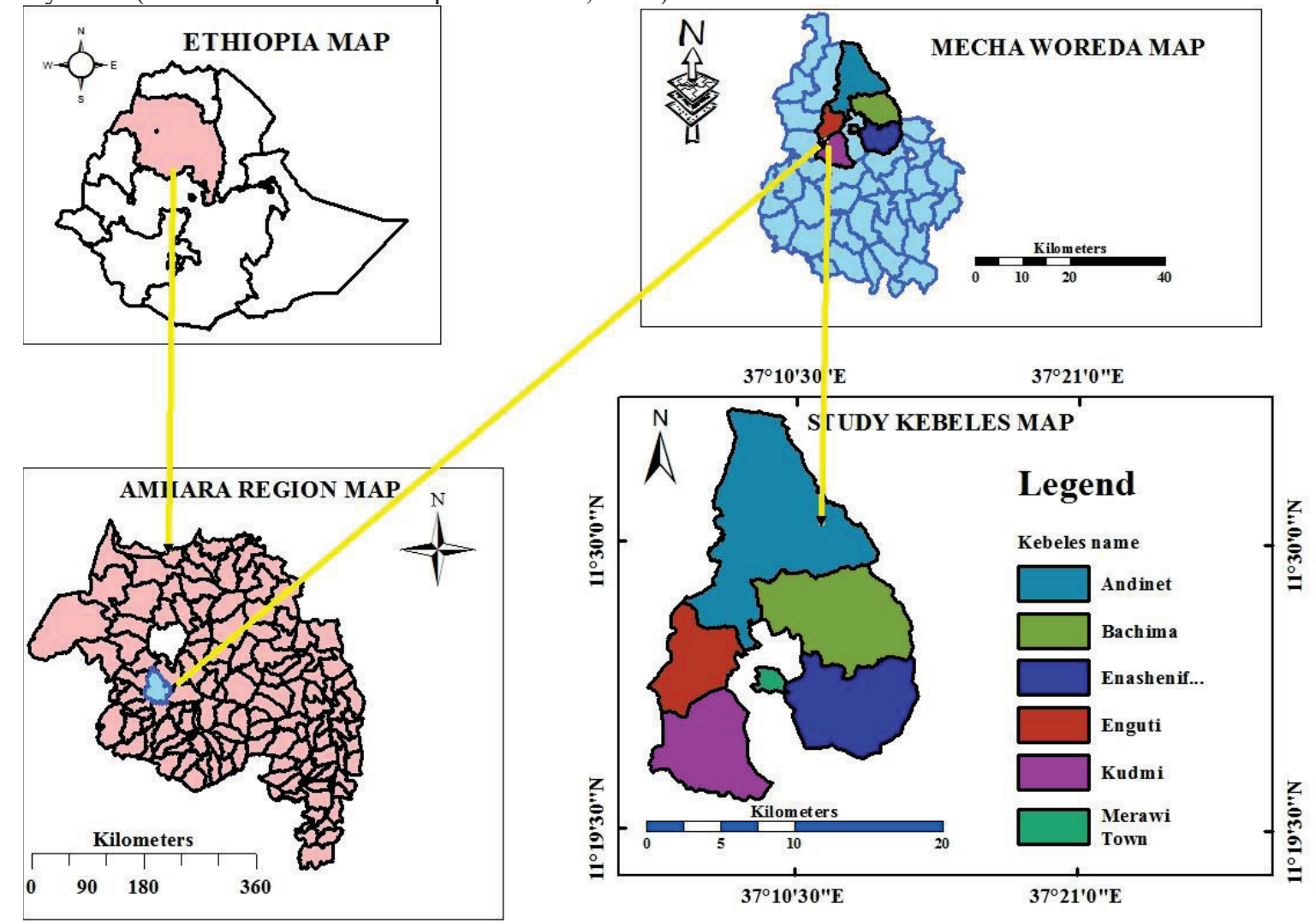

Source: Ethiopian GIS shape file

Figure 1. Map of study area 


\subsection{Data Types, Sources and Methods of Data Collection}

Both cross-sectional quantitative and qualitative data were collected from secondary and primary data sources. Secondary data sources were livestock husbandry and management experts; livestock product experts; annual reports, journals, and websites whereas primary data sources were smallholder dairy farmers. To collect these data both informal and formal survey methods were employed. In informal survey Focus Group discussion (FGD) was conducted whereas in formal survey, pretested semi-structured questionnaire which was translated to Amharic language was prepared to collect data from sampled small holder farmers. Quantitative data producers the amount of milk produced per day, the amount of milk sold, the amount of milk allocated to add value and the amount of milk allocated for home consumption were collected. Thus, the amount of butter, cheese, and whey produced were calculated using the conversion factor of milk for each milk products produced traditionally.

\subsection{Sampling Procedure and Sample Size Determination}

Sampling procedures: Purposive systematic random sampling technique was employed to determine sample size. Six kebeles were selected purposively based on the dairy production potential and milk market accessibility among 12 milk shed kebels in Mecha Woreda. Then, list of the smallholder milk producers were accessed in each selected kebele. List of milk producers were arranged in order of milking cows holding and then respondents were selected using systematic random sampling technique. The skip interval (K) was determined by dividing the population of each keble $(\mathrm{P})$ to sample size(S), that is, $K=\frac{P}{S}$. Thus, every $\mathrm{K}^{\text {th }}$ item from the list was selected and being the sampling element for this study.

Sample size determination: The total sample size for milk producers were determined by using Yamane formula (1977); $\quad \mathrm{n}=\frac{\mathrm{N}}{1+\mathrm{N}(\mathrm{e})^{2}} \rightarrow \boldsymbol{n}=\frac{1254}{1+1254(0.065)^{2}}=199 \sim 200$

Where $\mathrm{n}$ is the total sample size, $\mathrm{N}$ is the total population and $\mathrm{e}$ is the precision level. Since the targeted population for the study is the milk producers who have currently lactating cows, the respondents of the study come homogenous relative to all milk producers in the study area. Thus, Yamane formula with the precision level of $6.5 \%$ was employed to represent the population. The sample size of the milk producers in each kebele was determined using proportionate sampling method. Thus, face to face interview was undertaken with the total of 200 milk producers. Focused group discussion was conducted with 12 small holder milk producers to dig out the traditional milk products at farm level.

\subsection{Methods of Data Analysis}

Descriptive statistics such as frequency, means, ratios, percentages, standard deviations were used to analyse the survey data collected from smallholder milk producers and econometric models; bivariate probit and Tobit models were used to undertake econometric analysis using STATA 14.

\subsubsection{Econometric model specification \\ Bivariate probit model:}

In many practical economic applications economic actors' choices are restricted. In this study, 54\% of milk producers did not participate in raw milk marketing and whereas $38 \%$ of them did not participate in milk value addition. In each economic activity binary choices (to participate or not to participate) were overlooked. Participation decision by milk producers is the binary response variable that probability model can be developed with three approaches; linear probability, logit and probit model. Linear probability model (LPM) worked with OLS approach but it could not fulfill the underlying assumptions of OLS. Logit and probit models are alternative models that can avoid the defects of LPM (Wooldridge, 2012). Logit model is mainly employed for logistic distribution and practically applied for growth phenomenon such as population, GNP, money supply etc. whereas probit (normit ) model is applied for normal distribution (Gujarati, 2003). In this study the cumulative distribution function (CDF) of the dependent variables were assumed to be normal and maximum likelihood is an efficient and appropriate estimator (Greene, 2012). Thus, probit model can be applied to estimate the binary dependent variables parameters, determinants of raw milk marketing and milk value addition participation decisions. However, separate probit model could not applied since raw milk marketing participation decision and value addition participation decision are correlated negatively and the spearman correlation coefficient (rho) showed significant interdependence between raw milk supply decision and milk value addition decision. Therefore, bivariate probit model enables to evaluate the association of dependent variables and the marginal effects of covariates (Kohler and Rodgers, 1999). If correlation coefficient between probit equations were zero, the bivariate probit model became two independent univarite probit models (Cotei and Farhat, 2011 and Green, 2012).

The general specification of bivariate probit equation model;

$y_{1}{ }^{*}=x_{1} \beta+\varepsilon_{1}, y_{1}=1, y_{1}{ }^{*}>0,0$ otherwise

$y_{2}{ }^{*}=x_{2} \beta+\varepsilon_{2}, y_{2}=1, y_{2}{ }^{*}>0,0$ otherwise 


$$
\left(\begin{array}{l}
\varepsilon_{1} \\
\varepsilon_{2}
\end{array} / x_{1}, x_{2}\right) \sim N\left[\left(\begin{array}{l}
0 \\
0
\end{array}\right),\left(\begin{array}{ll}
1 & \rho \\
\rho & 1
\end{array}\right)\right]
$$

Where $y_{1}{ }^{*}$ and $y_{2}{ }^{*}$ are raw milk marketing participation decision and milk value addition participation decision respectively and $\varepsilon_{1}$ and $\varepsilon_{2}$ are error terms which are assumed to be distributed normally (Greene,2012). Since the two separate probit models have specific independent variables, seemingly unrelated probit model was employed. The probit model in milk market participation decision showed the 1 failure and 0 success completely determined so that milk market experience was excluded from the model.

\section{Bivarite Tobit model:}

Two dependent variables, raw milk supply participation intensity and value addition participation intensity were expressed in percentage that their value laid between 0 and 1. After specifying linear functional relationship, OLS assumptions tests, independence and simultaneity tests; and identification issues were assessed. Variance inflation factor (VIF) was employed to detect the multicollinearity problem. VIF estimates how much the variance of a regression coefficient is inflated due to multicollinearity in the model. Variance inflation factor can be calculated by;

$$
V I F=\frac{1}{1-R^{2}}
$$

VIF above 10 indicates the multicollinearity problem. The VIF values of independent variables were below 2.26 and the mean VIF was 1.49 in milk supply participation intensity regression model. The values indicate that there was no multicollnearity problem in the model. The normality distribution of the error term was tested by Shapro-Wilk test for normal data had p-value 0.39 and the null hypothesis of normality was accepted. The tests; heteroscedasticity and omitted variable tests indicated that non-constant variance of error term and the model has omitted variables. Heteroscedasticity can be happened due to either the presence of outliers in the data or omission of variable from the model. In the case of this study, there was no an outlier and the error terms are normally distributed. On the other hand, as the omitted variables test indicated that there could be the problem of model misspecification. To assure whether there were model misspecification, link test was applied. Link test can be applied for any single equation to test misspecification of the model. About $63 \%$ percent of the model was explained by independent variables. The p-value in the linktest of this model after regression was 0.11 and the null hypothesis of good specification was accepted. From these perspectives we are sure that heteroschedasticity is not due to misspecification of the model.

With similar fashion of raw milk supply participation level equation, all tests were conducted in value addition participation level equation. The VIF values of explanatory variables were below 2.24 and the mean value of VIF was 1.5 which shows there was no multicollenearity problem in the model. The normality test of error term by qnorm plot and kdensity shows normality. The heteroschedasticty and omitted variable test indicates that there was no hetteroschedasticity problem and no omitted variable and no misspecification problem respectively. Link test of the model showed that there is good model speciation.

Before estimation of the parameters, two important issues of independence and simultaneity were examined. Dependent variables were correlated negatively and significant at $1 \%$ significant level with correlation coefficient of -0.77 . Under spearman independence test, the spearman correlation coefficient (rho) was -0.74 which was statistically significant at $1 \%$ significant level. The test showed that the null hypothesis of independence of two variables was rejected, they are interdependent.

Practically as producers' value addition participation intensity at farm level increases, it shares the amount of raw milk supplied that is the raw milk supply participation intensity decreases and vice versa. Thus, these two variables may have cause and effect relation. To test simultaneity, a version of the Hausman specification error test was employed. In this t-test, the coefficient of the residual of raw milk supply was significant at $1 \%$ significant level in value addition equation whereas the residual of value addition equation was not significant in milk supply equation. This situation implied that raw milk supply causes value addition negatively but value addition did not cause milk supply participation level to increase or decrease. In general, it was assured that the two systems of equations were strongly interdependent and had recursive or unidirectional relationships.

With above procedures, we arrived at the conclusion of two equations were recursive simultaneous censored equations. In structural equations, the issue of identification must be assessed prior to estimation. If the equation is under-identified, the structure of the equation is not unique or there is not sufficient information to distinguish the equation. If the equation is just identified, there is sufficient information available to distinguish the equation. If the equation is over identified, there is more than sufficient information regarding the equation. In this study, the order condition of identification method indicated both equations are over identified. Order condition method is the necessary but not sufficient identification method while rank condition is necessary and sufficient condition of identification method. The rank condition of identification was employed and indicated both equations are just identified. Thus, since the order condition and rank condition were satisfied the equations were over identified. 
Models like Tobit (Tobin, 1958), Double Hurdle or Cragg's(Cragg, 1971) and Heckman selection model (Heckman, 1979) can be applied for single limited dependent variable. However these model frameworks are not applicable to situations when there are two or more correlated limited dependent variables. Applying univariate model analysis by neglecting interdependence and simultaneity problem causes an estimator for separate analysis to be inconsistent (Chen, 1997) and biased estimates of parameters (Hsiao, 1986; Yoo, 2005). Thus; Amemiya (1974) was first considered bivariate Tobit to analyze joint determination of censored dependent variables. For this study, recursive bivariate Tobit model was proposed to be appropriate in order to account censoring, interdependence and endogeneity that can exist due to simultaneity. Previous study conducted by Zenebe (2014) and Ali (2017) looked at milk market participations and value addition participation intensity determinants with separate model and nothing was expressed about the interdependence of two equations. On the other hand, different researchers applied bivariate and multivariate Tobit for their studies. For instance; Yoo (2005) applied bivariate Tobit to identify determinant of household bottled water and water purifier expenditures; and Kubanychbekova (2013) also applied to identify factors affecting parents' time allocation for children. Zhang et al (2017) used multivariate tobit to identify the effect of off-farm employment on forestland transfers in China; Rahman and Chima (2016) used multivariate Tobit to identify determinants of food crop diversity and profitability in southeastern Nigeria. Therefore, simultaneous (recursive) bivariate Tobit was used to estimate the parameter to account for the potential interdependent, endogenous and censored issues.

Structural equation of the model was specified as;

$$
\begin{aligned}
& r_{1 i}{ }^{*}=x_{1 i} \beta_{1}+\varepsilon_{1 i}, r_{1 i=} \max \left(r_{1 i}{ }^{*}, 0\right) \\
& v 2_{i}{ }^{*}=x_{2 i} \beta_{2}+\delta r_{1 i}^{*}+\varepsilon_{2 i}, v 2_{i}=\max \left(v 2_{i}{ }^{*}, 0\right)
\end{aligned}
$$

The reduced form of equation can be written as;

$$
\begin{aligned}
& r_{1 i}{ }^{*}=x_{1 i} c_{1}+\mu_{1 i}, r_{1 i}=\max \left(r_{1 i}{ }^{*}, 0\right) \\
& v 2_{i}{ }^{*}=x_{2 i} c_{2}+\mu_{2 i}, v 2_{i}=\max \left(v 2_{i}{ }^{*}, 0\right)
\end{aligned}
$$

Where the superscript asterisk represents the unobservable latent variables; $\boldsymbol{x}_{\mathbf{1} i}$ and $\boldsymbol{x}_{\mathbf{2} i}$ are the vectors of exogenous variables including constant term, $\varepsilon_{1 i}$ and $\varepsilon_{2 i}$ are random disturbances that follow bivariate normal distribution $B V N(0, \Omega)$, where $\Omega$ is covariance matrix with the correlation coefficient $(\rho)$ between the error terms of two structural equations. Under reduced form equation $\mu_{1 i}$ and $\mu_{2 i}$ are random disturbances that follow univariate normal distribution $N \sim\left(0, \sigma^{2}\right)$. The Doornik-Hansen test was used for bivariate normality test and the null hypothesis of bivariate normality is accepted. The bivariate normal distribution of probability density function can be stated by;

$p\left(\boldsymbol{x}_{1}, \boldsymbol{x}_{2}\right)=\frac{1}{2 \pi \sigma_{1} \sigma_{2} \sqrt{1-\rho^{2}}} \exp \left[-\frac{z}{2\left(1-\rho^{2}\right)}\right]$

Where $z=\frac{\left(x_{1}-\mu_{1}\right)^{2}}{\sigma_{1}{ }^{2}}-2 \rho \frac{\left(x_{1-\mu_{1}}\right)\left(x_{2}-\mu_{2}\right)}{\sigma_{1 \sigma_{2}}}+\frac{\left(x_{2}-\mu_{2}\right)^{2}}{\sigma_{2}{ }^{2}}, \rho=\operatorname{cor}\left(\boldsymbol{x}_{1}, \boldsymbol{x}_{2}\right)=\frac{v_{12}}{\sigma_{1} \sigma_{2}}$ and $v_{12}$ is the covariance of $x_{1}$ and $x_{2}$.

Maximum likelihood is an indispensable estimator for nonlinear models. Maximum likelihood estimator is consistent and efficient estimator under identified regressors (low multicollenearity) and normal distribution of data (Green, 2012). Maximum likelihood estimators are sufficient, asymptotically efficient and unbiased if normality is satisfied. Even under non-normality distribution, maximum likelihood is more efficient than OLS as long as the distribution of the disturbances is correctly specified (Wooldridge 2002; Baltagi, 2008). Therefore, for this study maximum likelihood estimator is selected to estimate the parameters. For a random variable , $y_{i}$ and given set of parameters, $\theta$ the likelihood function is usually expressed by log:

$\ln L(\theta \mid y)=\sum_{i=1}^{n} \ln f\left(y_{i} \mid \theta\right)$

$$
\text { Where }\left(y_{i} \mid \theta\right)=\prod_{i=1}^{n} f\left(y_{i} \mid \theta\right)=L\left(\theta \mid y_{i}\right)
$$

A two-stage simultaneous equation procedure (proposed by Nelson and Olson) was employed to estimate structural parameter. The first stage was to regress the reduced form of equations (for equation 2) and used the coefficient estimates of $c_{2}$ to generate the predicted values of latent dependent variables. Secondly, the predicted value of the latent variables was used as instruments on the right-hand sides of the structural form equation. Finally a Tobit approach was applied to estimate parameters of the structural equations. The likelihood ratio (LR) test was conducted on the bivariate model with the null hypothesis of $\rho=0$. The corresponding statistics rejected the null hypothesis that indicated a bivariate Tobit estimator (maximum likelihood) should be employed with the Nelson-Olson procedure to attain more efficient estimates. 


\subsubsection{Definition of Variables and Hypotheses \\ Dependent variables:}

Milk supply participation decision (MPD) and intensity of participation (MPI): First, sampled households take a value of 1 if they participate in milk market and 0 otherwise. Secondly, households who participated in milk market take the percentage amount of milk sold to total milk produced and 0 otherwise.

Milk value addition participation decision (VAPD) and intensity of participation (VAPI): First, sampled households take a value of 1 if they participate in value addition and 0 otherwise. Secondly, households who participated in value addition take the percentage amount of milk sold to total milk produced and 0 otherwise.

Independent variables for milk market participation

Age of the household head (AGE): It is a continuous variable that is measured in year. Bardhan et al.(2012); Berhanu et al.(2014) and Chamboko et al. (2017) identified that age affected the probability of participating in milk marketing negatively and significantly. In contrast, Emukule et al.(2018) indicated that as age increases, there would be better milk production and marketing experience which in-turn increases the probability of milk market participation. Study by Chamboko et al. (2017) showed that age affected the volume of milk sold negatively whereas Emukule et al. (2018) inferred that age affected milk market participation intensity positively. Therefore, the effect of household head age on milk market participation decision and intensity participation was difficult to hypothesize.

Family size (FMSZ): It is a continuous variable measured in adult equivalent. As dairying and marketing are labor intensive activities, milk producers used family labor for these activities. Thus, family size is expected to have positive impact on milk market participation and intensity of participation. A study conducted by Benyam et al. (2016) indicated that family size affected milk market participation and level of participation positively. Emukule et al. (2018) identified household size was associated with the milk sell likelihood positively. In contrast, family size increases home milk consumption which affects the milk market participation. Berhanue et al. (2014) found that family size affected the volume of milk supply negatively. Thus, it was difficult to hypothesis the variable's effect on milk participation.

Education level (EDU): It is a discrete variable and is measured in the formal education class that a household head has attended. Education can capacitate the performance of farmers in farming, information sharing and technology implementation and then can improve the decision making quality (Fakoya et al., 2007). Studies by Chamboko et al.(2017) and Emukule et al. (2018) identified that education level affected the likelihood of milk sell positively. This variable was hypothesized to affect milk market participation decision and intensity of participation positively.

Land holding size (LNS): It is a continuous variable that is measured in hectare. Land is important input for forage and pasture development which enhances dairy production. It is expected that as land size increases, the household proportion land allocation for dairy production can be increased and then milk market participation increases. A study conducted by Chamboko et al. (2017) indicated that land size affected the level of milk sell positively. Emukule et al. (2018) identified land size affected the likelihood of milk sell positively while it affected the volume of milk sold negatively. Studies conducted by Berhanu et al. ( 2104) and D. Bardhan et al.(2012) indicated that land holding size of the household affected the probability of milk market participation and the volume of supply negatively. Therefore, it was difficult to hypothesize the effect of land holding size on milk market participation.

Number of local breed milking cows (NULC): It is a discrete variable measured in number. As the number of local milking cow increases, the volume of milk produced increases and producers would have surplus milk to sell. Benyam et al. (2016) identified that number of local dairy cows had positive relationship with milk market participation decision and amount of participation. Similarly, Chamboko et al. (2017) showed as the number of dairy cows increase milk market participation decision and level of participation would also increases. Therefore, this variable was hypothesized to affect milk market participation decision and intensity positively.

Number of cross breed milking cows (NUCRC): It is a discrete variable measured in number. Benyam et al. (2016) identified that number of cross milking cows had direct relationship with milk market participation. Bayan and Pratim (2018) pointed out that producers had cross breed were more commercial oriented than producers did not have. Therefore, this variable was hypothesized to affect milk market participation decision and participation intensity positively.

Dairy farming experience (DFMEXP): It is a continuous variable which is measured in year. It is expected that the experience of farmers in milk production influence the probability and level of milk market participation positively. Studies conducted by Zenebe (2014) and Berhanu et al. (2014) identified that dairy farming experience caused both the probability of milk market participation and volume of supply negatively. On the hand Selman et al. (2015) identified dairy farming experience influenced market participation decision level and intensity positively. Thus, it was difficult to hypothesize the effect of this variable on milk participation decision and intensity.

Volume of milk yield per day (sqrtMLY): It is a continuous variable that is measured in litter. It is expected 
that producers supply milk when they have large volume of milk at hand. Past studies conducted by Omiti et al. (2009); Bardhan et al. (2012); Berhanu et al. (2014) and Zenebe (2014) showed that the amount of milk produced per day affected the milk market participation decision and intensity positively. Therefore, this variable was hypothesized to affect milk market participation positively.

Volume of milk allocated for home consumption (MLCN): It is a continuous variable which is measured in litter. Household consume during regular days or/and during socio-cultural ceremonies. A study conducted by Luoga (2007) found that the amount of milk consumed per household was a highly significant indicator producers' failure to milk market participation. According to Karna (2015) and Ali (2017) the size of milk consumption was inversely related with butter participation decision and intensity. As more milk is required to allocate for family consumption, the probability of milk participation decision and volume of milk supply decline. Therefore, this variable was hypothesized to influence milk market participation negatively.

Membership to milk cooperatives (MEMCOOP): It is a dummy variable that take the value of 1 if a household is a member of cooperative and 0 otherwise. Chagwiza et al. (2016) revealed that cooperatives have strong roles in facilitating technology transformation and commercialization. The study conducted by Phon and Yamaji (2016) showed that membership in agricultural cooperatives improves participation decision and intensity in vegetable markets. Similarly, Kumar (2018) indicated dairy cooperative membership has positive impact on milk yield which enhances market participation. Therefore, membership to milk cooperative was hypothesized to affect milk market participation positively.

Distance of from the nearest dairy market (DSTM): It is a continuous variable measured in kilometer. As producers far from the market, they cannot access markets facilities; market information and infrastructure and incurred high transaction costs which discourage sellers to supply milk. Previous studies conducted by Omiti et al. (2009), D. Bardhan et al. (2012); Zenebe (2014) and Benyam et al. (2016) indicated that distance of market had indirect relationship with the likelihood of milk market participation decision and volume of supply. Therefore, distance of milk market was hypothesized to affect market participation decision and intensity negatively.

Livestock holding (TLU): It is a continuous variable which is measured total tropical livestock unit. In Ethiopia, shortage of grazing land, in general shortage of feed is the main constraint in dairy production (Mebrate et al., 2019). Extra cattle holding shares limited feed resources owned and decreases milk volume so that producers would not sell milk. Thus, this variable was hypothesized to affect milk participation decision and intensity negatively.

Milk market experience (MRKTEXP): It is a continuous variable that is measures in year. Experience in marketing helps to understand market opportunities. According to Kumar (2010) milk market experience influenced milk participation decision and intensity positively. The study conducted by Sigei et al. (2013) showed marketing experience influenced the extent of market participation positively in pineapple market. Mbitsemunda and Karangwa (2018) also showed market experience had direct influence on participation decision and extent of participation in bean market. Therefore, the variable was hypothesized to affect milk market participation decision and intensity positively.

Independent variables for value addition participation

Age of the household head (AGE): It is a continuous variable that is measured in year. Older household can have more dairy cows and volume of milk and have higher probability to add value than younger. Tadele et al. (2014) found age has positive association with value addition participation decision. Similarly, Karna (2015) and Benyam et al. (2017) identified age of the household is positively associated with the likelihood to add value to milk. Therefore, the variable is hypothesized to affect milk value addition participation and intensity of participation positively.

Family size (TOTFM): It is a continuous variable measured in adult equivalent. Embaye, (2015) identified that family size tended to decrease the likelihood of selling butter. However, a study conducted by Ali (2017) showed that as family size increases, the value addition participation and its intensity increases. Similarly, Tsega et al. (2017) showed family size affected probability of participation in milk value addition positively. Therefore, it was difficult to hypothesize this variable on milk value addition participation.

Land holding size (LNS): It is a continuous variable that is measured in hectare. According to Ali, (2017) study result ,land holding size had negative relationship with household likelihood of value addition and level of value addition participation. Thus, this variable was hypothesized to affect value addition participation decision and intensity of participation negatively.

Number of local breed milking cows (NULC): It is a discrete variable measured in number. Due to the higher fat content local dairy cows' milk than cross dairy cows' milk, producers prefer to processes the local dairy cow milk. High number local dairy cows encourage milk processing and add value to milk. Study by Tadele et al. (2014) showed that number of local milking cows had positive effect on milk value addition decision and amount. In contrast, Ali (2017) found that number of local breed milking cows had negative effect of value addition participation decision and intensity. Hence, it was difficult to hypothesize the influence on value addition 
decision and intensity positively.

Number of cross breed milking cows (NUCRC): It is a discrete variable measured in number. Dairying cross milking cows enables to produce large milk volume. Producers prefer more to sell milk of cross cows than to process due to less fat content of cross cow milk. Tadele et al. (2014) and Tsega et al. (2017) indicated number cross dairy cows affected milk value addition participation negatively. Thus, this variable was hypothesized to affect milk value addition participation negatively.

Dairy farming experience (DFMEXP): It is a continuous variable which is measured in year. As producers experienced in dairying, they probably improve their production system and amount of production. Producers with large volume of milk prefer selling to processing milk. Karna (2015) found that dairy experience of farmers affected the likelihood of value addition to milk negatively and significantly. Thus, this variable was hypothesized to affect value addition negatively.

Membership to milk cooperatives (MEMCOOP): It is a dummy variable that take the value of 1 if a household is a member of cooperative and 0 otherwise. Milk producers who are not member cooperative participate more in milk value addition than cooperative members. The study conducted by Ali (2017) and Tsega et al. (2017) showed that as dairy producers switched from non-member to member of dairy cooperative, their value addition participation decision as well as level of participation in milk value addition would decline. Thus, cooperative membership was hypothesized to affect milk value addition participation positively.

Volume of milk yield per day (sqrtMLY): It is continuous variable measured in litter. Households have a chance to allocate certain amount of milk that goes to value addition when milk volume per day is high. Tadele et al. (2014); Karna, (2015); Betela et al. (2017) and Tsega et al. (2017) found that increase in milk yield per day enhanced milk value addition participation. In contrast, study conducted by Ali (2017) identified that milk yield per day had negative association with probability of value addition and volume of value addition. Therefore, this variable was difficult to hypothesize the effect on value addition participation decision and intensity.

Distance of from the nearest dairy market (DSTM): It is a continuous variable measured in kilometer. Tadele et al. (2014) identified distance of market had positive effect on milk value addition participation decision and intensity. In contrast, Embaye (2015) identified distance of dairy market affected butter supply decision and level of butter negatively. Karna (2015) identified distance of market is associated with value addition participation decision negatively whereas it is directly associated with level of value addition. Therefore, it was difficult to hypothesize the effect of market distance on value addition participation.

Value addition experience (VLADEXP): It is a continuous variable that is measured in year which indicates the year that household engaged in value addition. Experience in value addition enhances knowledge on milk processing and marketing activities. Ngore (2010) and Tijani (2018) indicated year of market experience had positive association with probability of participation and amount of supply in butter market. Thus, this variable was hypothesized to affect milk value addition participation decision and intensity positively.

Livestock holding (TLU): It is a continuous variable that is measured in tropical livestock unit. Holding large herd size share the feed resource of lactating cows and milk productivity probably decrease. Low milk volume discourages value addition participation decision and intensity and produces use milk for self-consumption. Study conducted by Dirriba and Lemma (2016) indicated that livestock size and butter market participation decision as well as level of participation had negative relationship. Therefore, this variable was hypothesized to affect value addition participation negatively.

\section{RESULTS AND DISCUSSIONS}

\subsection{Descriptive Results}

\section{Demographic and socio-economic characteristics of sampled milk producers}

Of the total respondents, female household heads accounted only $7.5 \%$. More than $90 \%$ of the respondents were married. Small holder farmers practiced mixed farming practice and of the total respondents about $68.8 \%$ of them lead their livelihood with crop cultivation and about $19.6 \%$ of the respondents replied as their major livelihood is dairy farming. This implied that though dairying is less support in livelihood relative to cropping, farmers begun to realize dairy production can be as business beyond home nutrition fulfillment. The average age of the respondents was 45 years and their average educational status in class year completion was 2.8. Milk producers traveled $5 \mathrm{~km}$ on average to sell milk and milk products. Whereas, when a household wanted to visit their livestock to veterinary clinic, he /she traveled $2.6 \mathrm{~km}$ on average (Table 5). 
Table 1. Socio-demographic Characteristics of sampled producers

\begin{tabular}{llll}
\hline Variables & & Number & Percent \\
\hline Sex & Female & 15 & 7.5 \\
& Male & 185 & 92.5 \\
\hline Marital status & single & 11 & 5.56 \\
& married & 181 & 91.41 \\
& widow & 3 & 1.52 \\
& Divorce & 3 & 1.52 \\
\hline Religion & Orthodox & 181 & 90.95 \\
& Protestant & 18 & 9.05 \\
\hline Major livelihood & crop cultivation & 137 & 68.84 \\
& dairy & 39 & 19.60 \\
& government employment & 8 & 4.02 \\
& crop and dairy & 11 & 5.53 \\
& dairy and merchant & 4 & 2.01 \\
\hline Variables & Mean : N=200 & SD. & Min(Max) \\
\hline Family size (ADE) & 5.482 & 1.976 & $0.75(9.450)$ \\
Age (year) & 44.970 & 10.970 & $20.0(68.0)$ \\
Education (year) & 2.799 & 3.060 & $0.00(10.0)$ \\
Distance of veterinary clinic( (km) & 2.6 & 1.9 & $0.10(9)$ \\
Distance of dairy product market(Km) & 5.029 & 1.874 & $1.015(8.6)$ \\
\hline
\end{tabular}

On average, dairy farmer produced and consumed 9.5 and 1.3 litters of milk per day respectively. The average total land holding size of the household was 1.44 hectare. A respondent held about 5 total livestock on average. He/she held nearly one 0.6 and 21.8 cross lactating dairy cows on average. Hence the raw milk market was under-development; respondents had lower experience in milk participation than value addition.

Household dairy products market participation: The mean proportion mean in the summary indicates that from sampled respondents $46 \%$ and $62 \%$ of them were participating in raw milk marketing and value addition respectively. The mean raw milk market and value addition participation intensity of sample household was $32.1 \%$ and $39.3 \%$ respectively. Raw milk market participation is newly immerged economic activity in the study area. The average milk market experience of a household was 1.5 years while the value addition experience was 8.9 years (Table 6).

Table 2.Summary statistics for dairy market participation and asset holding

\begin{tabular}{lllll}
\hline Variables & Mean $: \mathrm{N}=200$ & SD. & Min & Max \\
\hline Milk market participation decision (0/1) & 0.460 & 0.500 & 0.000 & 1.00 \\
Value addition participation decision (0/1) & 0.620 & 0.487 & 0.000 & 1.000 \\
Cooperative membership (0/1) & 0.310 & 0.464 & 0.000 & 1.000 \\
Raw milk market participation intensity (0/1) & 0.321 & 0.372 & 0.000 & 0.932 \\
Value addition participation intensity (0/1) & 0.393 & 0.324 & 0.000 & 0.875 \\
value addition experience (year) & 8.938 & 4.637 & 1.015 & 20.585 \\
Milk market experience (year) & 1.504 & 1.882 & 0.000 & 7.500 \\
Total land size (hectare) & 1.460 & 1.014 & 0.000 & 3.950 \\
Land allocated for crop & 0.818 & 0.767 & 0.000 & 3.250 \\
Land allocated for forest & 0.224 & 0.435 & 0.000 & 5.000 \\
Land allocated for grazing & 0.418 & 0.413 & 0.000 & 1.750 \\
Number of local cow (number) & 0.570 & 0.754 & 0.000 & 3.000 \\
number of cross cow (number) & 1.780 & 0.809 & 1.000 & 4.000 \\
Dairy farming experience (year) & 8.230 & 2.783 & 2.000 & 15.000 \\
Milk yield (litter) per day/HH & 9.55 & 5.33 & 0.8 & 23.00 \\
Milk consumption (litter) & 1.348 & 0.673 & 0.276 & 3.064 \\
livestock holing (TLU) & 5.376 & 2.410 & 1.700 & 10.180 \\
\hline
\end{tabular}

Land holding and allocation: Farmers undertook mixed agricultural practices, both crop and livestock. The major crops grown in the area are maize, millet, wheat, teff, and vegetables. Eucalyptus is the major cash crop that supports the livelihood of farmers. As a result farmers allocated their land for eucalyptus next to crop production. According to this survey calculation about 56.1 and 28.6 percent of land was allocated for crop and forest production respectively. Land allocation for forest production usually indicates the eucalyptus production in the area. The remaining portion land $(15.3 \%$ of land) was allocated for livestock production (grazing). A farmer held 1.46 hectare of land on average which is higher than the national average land holding size per households , 1.04 hectare (CSA , 2018). 
Livestock holding: The average size lactating cows holding size was about 2 per household whereas a house hold had a total of 5 livestock size (TLU) on average. Milk producers kept local lows mainly for milk consumption and butter production whereas cross dairy cows were targeted to sell raw milk but they also added value to milk ( process and sell ) when raw milk demand became low. Milk producers, who had only local lactating cows, did not participate in raw milk marketing. Besides raw milk marketing, milk producers used calves for selling live and made it as source of home income. Farmers kept female calves for rearing unless they incurred feed shortage but male calves were used for live marketing.

\subsection{Inferential Statistics Results}

The mean comparison T-test in table 8 below shows that the mean proportions of milk market participation decision between participants and non-participates are statistically different and significant at $1 \%$ significant level. Similarly, mean proportions of value addition participation decision are significantly different at $1 \%$ significant level. The means of participation intensity between participants and non-participants are significantly different at $1 \%$ significant level both in milk market and value addition participation.

In raw milk market participation, of the total 14 independent variables the means of 13 variables between participants and non-participants are different and statistically significant. The means of milk yield per day, age of the household head, and land holding size between participants and non-participants are different significantly at $5 \%$ significant level. The means of household education level and total livestock holding between participants and non-participants are statically and significantly different at $10 \%$ significant level. The means of the remaining 8 independent variables; dairy farm experience, milk market experience, value addition experience, number of local cows ,number of cross cows, distance of dairy products market, household milk consumption and membership in dairy cooperative between participants and non-participants are significantly different at $1 \%$ significant level.

In milk value addition participation, the means of 8 independent variables are significantly different. The means of household head age, family size, dairy farm experience, and distance of dairy product market are significantly different at 5\% significant level. The means of land holding, value addition experience, number of local cows, and membership in dairy cooperative are significantly different at $1 \%$ significant level.

Table 3. Descriptive and inferential statistics of variables used in regression

\begin{tabular}{|c|c|c|c|c|c|c|}
\hline \multirow[t]{3}{*}{ Variables } & \multicolumn{3}{|c|}{ Milk market participation } & \multicolumn{3}{|c|}{ Value addition participation } \\
\hline & $\begin{array}{l}\text { No } \\
n=108\end{array}$ & $\begin{array}{l}\text { Yes } \\
n=92\end{array}$ & & $\begin{array}{l}\text { No } \\
n=124\end{array}$ & $\begin{array}{l}\text { Yes } \\
n=76\end{array}$ & \\
\hline & $\begin{array}{l}\text { mean } \\
(\mathrm{SD})\end{array}$ & $\begin{array}{l}\text { mean } \\
(\mathrm{SD})\end{array}$ & t-value & $\begin{array}{l}\text { mean } \\
(\mathrm{SD})\end{array}$ & $\begin{array}{l}\text { mean } \\
(\mathrm{SD})\end{array}$ & t-value \\
\hline MPD & & & & $\begin{array}{l}0.724 \\
(0.45)\end{array}$ & $\begin{array}{l}0.298 \\
(0.459)\end{array}$ & $6.4 * * *$ \\
\hline VAPD & $\begin{array}{l}0.805 \\
(0.397)\end{array}$ & $\begin{array}{l}0.402 \\
(0.493)\end{array}$ & $6.4 * * *$ & NA & NA & \\
\hline MPI & 0.00 & $\begin{array}{l}69.8 \\
(19.1)\end{array}$ & $-37.97 * * *$ & $\begin{array}{l}59.8 \\
(37.97)\end{array}$ & $\begin{array}{l}15.1 \\
(24.33)\end{array}$ & $10.15 * * *$ \\
\hline VAPI & $\begin{array}{l}59.4 \\
(27.07)\end{array}$ & $\begin{array}{l}15.6 \\
(12.86)\end{array}$ & $14.97 * * *$ & $\begin{array}{l}5.7 \\
(18.7)\end{array}$ & $\begin{array}{l}59.8 \\
(19.04)\end{array}$ & $-19.6 * * *$ \\
\hline MLY & $\begin{array}{l}6.69 \\
(3.44)\end{array}$ & $\begin{array}{l}12.91 \\
(5.21)\end{array}$ & $-10.10 * *$ & $\begin{array}{l}9.85 \\
(5.57)\end{array}$ & $\begin{array}{l}9.35 \\
(5.19)\end{array}$ & 0.64 \\
\hline $\mathrm{AG}$ & $\begin{array}{l}47.11 \\
(9.94)\end{array}$ & $42.46(11.62)$ & $3.05 * *$ & $\begin{array}{l}41.96 \\
(11.78)\end{array}$ & $\begin{array}{c}46.89 \\
(9.99)\end{array}$ & $-3.1710 * *$ \\
\hline EDU & $\begin{array}{l}2.42 \\
(2.80)\end{array}$ & $\begin{array}{l}3.24 \\
(3.30)\end{array}$ & $-1.89 *$ & $\begin{array}{l}3.03 \\
(3.35)\end{array}$ & $\begin{array}{l}2.65 \\
(2.86)\end{array}$ & 0.87 \\
\hline FMLSZ & $\begin{array}{l}5.67 \\
(1.81)\end{array}$ & $\begin{array}{l}5.26 \\
(2.14)\end{array}$ & 1.47 & $\begin{array}{l}4.98 \\
(1.96)\end{array}$ & $\begin{array}{l}5.8 \\
(1.92)\end{array}$ & $-2.96 * *$ \\
\hline TLU & $\begin{array}{l}5.71 \\
(2.43)\end{array}$ & $\begin{array}{l}4.98 \\
(2.33)\end{array}$ & $2.1573 *$ & $\begin{array}{l}4.77 \\
(2.22)\end{array}$ & $\begin{array}{l}5.76 \\
(2.46)\end{array}$ & $-2.88 * *$ \\
\hline LNS & $\begin{array}{l}1.64 \\
(0.95)\end{array}$ & $\begin{array}{l}1.21 \\
(1.04)\end{array}$ & $3.07 * *$ & $\begin{array}{l}1.069 \\
(0.99)\end{array}$ & $\begin{array}{l}1.68 \\
(0.96)\end{array}$ & $-4.3 * * *$ \\
\hline DFMEXP & $\begin{array}{l}5.20 \\
(3.30)\end{array}$ & $\begin{array}{l}6.97 \\
(3.35)\end{array}$ & $-3.74 * * *$ & $\begin{array}{l}6.49 \\
(3.49)\end{array}$ & $\begin{array}{l}5.71 \\
(3.38)\end{array}$ & $2.00 * *$ \\
\hline MRKTEXP & $\begin{array}{l}1.00 \\
(1.78)\end{array}$ & $\begin{array}{l}2.78 \\
(1.99)\end{array}$ & $-6.65 * * *$ & $\begin{array}{l}1.90 \\
(1.89)\end{array}$ & $\begin{array}{l}1.77 \\
(2.19)\end{array}$ & 0.45 \\
\hline VLADEXP & $\begin{array}{l}9.7 \\
(4.83)\end{array}$ & $\begin{array}{l}8 \\
(4.23)\end{array}$ & $2.6 * * *$ & $\begin{array}{l}7.79 \\
(4.65)\end{array}$ & $\begin{array}{l}9.67 \\
(4.49)\end{array}$ & $-2.9 * * *$ \\
\hline NULC & $\begin{array}{l}0.81 \\
(0.79)\end{array}$ & $\begin{array}{l}0.26 \\
(0.57)\end{array}$ & $5.61 * * *$ & $\begin{array}{l}0.32 \\
(0.61)\end{array}$ & $\begin{array}{l}0.71 \\
(0.78) \\
\end{array}$ & $-3.74 * * *$ \\
\hline
\end{tabular}




\begin{tabular}{|c|c|c|c|c|c|c|}
\hline \multirow[t]{3}{*}{ Variables } & \multicolumn{3}{|c|}{ Milk market participation } & \multicolumn{3}{|c|}{ Value addition participation } \\
\hline & $\begin{array}{l}\text { No } \\
n=108\end{array}$ & $\begin{array}{l}\text { Yes } \\
n=92\end{array}$ & & $\begin{array}{l}\text { No } \\
n=124\end{array}$ & $\begin{array}{l}\text { Yes } \\
n=76\end{array}$ & \\
\hline & $\begin{array}{l}\text { mean } \\
(\mathrm{SD})\end{array}$ & $\begin{array}{l}\text { mean } \\
(\mathrm{SD})\end{array}$ & t-value & $\begin{array}{l}\text { mean } \\
(\mathrm{SD})\end{array}$ & $\begin{array}{l}\text { mean } \\
(\mathrm{SD})\end{array}$ & t-value \\
\hline NUCRC & $\begin{array}{l}1.49 \\
(0.66)\end{array}$ & $\begin{array}{l}2.14 \\
(0.86)\end{array}$ & $-6.04 * * *$ & $\begin{array}{l}1.94 \\
(0.88)\end{array}$ & $\begin{array}{l}1.69 \\
(0.77)\end{array}$ & 2.02 \\
\hline DSTM & $\begin{array}{l}5.71 \\
(1.82)\end{array}$ & $\begin{array}{l}4.23 \\
(1.61)\end{array}$ & $6.05 * * *$ & $\begin{array}{l}4.49 \\
(1.67)\end{array}$ & $\begin{array}{l}5.37 \\
(1.91)\end{array}$ & $-3.31 * *$ \\
\hline MLCN & $\begin{array}{l}1.60 \\
(0.68)\end{array}$ & $\begin{array}{l}1.10 \\
(0.54)\end{array}$ & $5.82 * * *$ & $\begin{array}{l}1.37 \\
(0.77)\end{array}$ & $\begin{array}{l}1.33 \\
(0.60)\end{array}$ & 0.47 \\
\hline MEMCOOP & $\begin{array}{l}0.11 \\
(0.31)\end{array}$ & $\begin{array}{l}0.54 \\
(0.50)\end{array}$ & $-7.4 * * *$ & $\begin{array}{l}0.43 \\
(0.49)\end{array}$ & $\begin{array}{l}0.23 \\
(0.42)\end{array}$ & $3.02 * * *$ \\
\hline
\end{tabular}

The value ***, ** and *represents statistical probability level at $1 \%, 5 \%$ and $10 \%$, respectively

Source: survey result, 2019

\subsection{Econometric Model Results}

\subsubsection{Bivariate probit model results}

Dependent variables; raw milk supply decision and value addition decisions were suspected as they were interdependent. The Spearman independence test $(\rho=-0.414)$ showed that there is interdependency between raw milk supply and value addition decision. The Wald test of the correlation coefficient of rho (-0.82) was significant at $1 \%$ significant level. Thus, bivariate probit model is appropriate to estimate parameters.

All explanatory variables found in raw milk market supply decision equation did not found in value addition participation decision equation. Thus, seemingly unrelated bivariate probit model was used. Among types marginal effects average marginal effect was preferred with its advantages in taking into considerations of any covariates in the model (spring, 2013; Leeper, 2017). The probability of the household to supply raw milk was significantly affected by 8 variables in the model.

Table 4. Determinants raw milk market and value addition participation decision, bivariate probit result

\begin{tabular}{|c|c|c|c|c|c|c|c|c|}
\hline \multirow[t]{2}{*}{ MPD } & \multirow[b]{2}{*}{ Coef. } & \multirow[b]{2}{*}{$\mathrm{dy} / \mathrm{dx}$} & \multicolumn{6}{|c|}{ VALPD } \\
\hline & & & std.e & $\mathrm{Z}$ & coeficec & $\mathrm{dy} / \mathrm{dx}$ & std.er. & $\mathrm{Z}$ \\
\hline $\mathrm{AG}$ & -0.027 & -0.003 & 0.002 & $-1.67 *$ & 0.015 & 0.005 & 0.003 & 1.37 \\
\hline FMLSZ & 0.136 & 0.018 & 0.011 & $1.65^{*}$ & 0.020 & 0.006 & 0.017 & 0.36 \\
\hline EDU & -0.034 & -0.004 & 0.005 & -0.89 & & & & \\
\hline LNS & -0.252 & -0.032 & 0.023 & -1.39 & 0.333 & 0.105 & 0.034 & $3.1 * * *$ \\
\hline NULC & -0.442 & -0.057 & 0.031 & $-1.86^{*}$ & 0.150 & 0.047 & 0.057 & 0.83 \\
\hline NUCRC & 0.085 & 0.011 & 0.031 & 0.35 & -0.109 & -0.034 & 0.053 & -0.65 \\
\hline DFMEXP & 0.106 & 0.014 & 0.006 & $2.41 * *$ & -0.065 & -0.020 & 0.011 & $-1.91 * *$ \\
\hline sqrtMLY & 1.684 & 0.216 & 0.027 & $7.97 * * *$ & 0.182 & 0.057 & 0.042 & 1.380 \\
\hline MLCN & -1.713 & -0.220 & 0.030 & $-7.23 * * *$ & & & & \\
\hline MEMCOOP & 0.977 & 0.126 & 0.033 & $3.79 * * *$ & -0.376 & -0.118 & 0.070 & $-1.69 *$ \\
\hline DSTM & -0.154 & -0.020 & 0.009 & $-2.12 * *$ & 0.067 & 0.021 & 0.019 & 1.12 \\
\hline TLU & 0.038 & 0.005 & 0.050 & 0.10 & 0.121 & 0.038 & 0.085 & 0.45 \\
\hline VLADEXP & 0.040 & & & & & 0.013 & 0.006 & $1.99 * *$ \\
\hline constant & $-1.923 * *$ & & & & $-1.687 * *$ & & & \\
\hline /athrho & -1.259 & & 0.269 & -4.680 & & & & \\
\hline rho & -0.85 & & 0.074 & & & & & \\
\hline \multicolumn{3}{|c|}{ Number of observations } & & 200 & & & & \\
\hline \multicolumn{3}{|c|}{ Log pseudo- likelihood } & & -137.09 & & & & \\
\hline \multicolumn{3}{|c|}{ Wald $X^{2}(23), P r>X^{2}$} & & $122.76^{* * *}$ & & & & \\
\hline \multicolumn{3}{|c|}{ Wald test of rho $=0, P r>X$} & & $21.93 * * *$ & & & & \\
\hline
\end{tabular}

The value $* * *, * *$ and $*$ represents statistical probability level at $1 \%, 5 \%$ and $10 \%$, respectively Source: survey result, 2019

\subsubsection{Recursive bivariate Tobit model results}

Econometric model result shows that, of total 14 variables, raw milk supply participation level was affected by 8 variables significantly whereas 5 variables affected value addition participation intensity of the household in farm level significantly. 
Table 5. Determinants $\mathrm{r}$ aw milk market and value addition participation intensity Bivariate Tobit result

\begin{tabular}{|c|c|c|c|c|c|c|}
\hline \multirow[t]{2}{*}{ MPI } & & & & \multicolumn{3}{|c|}{ VAPI } \\
\hline & Coef. & Std. Err. & z-value & coef. & Std.Err & z-value \\
\hline MPI & & & & -0.024 & 0.205 & -0.120 \\
\hline $\mathrm{AG}$ & -0.003 & 0.002 & -1.26 & 0.002 & 0.003 & 0.720 \\
\hline FMLSZ & 0.018 & 0.013 & 1.37 & 0.004 & 0.014 & 0.290 \\
\hline EDU & 0.005 & 0.005 & 1.15 & & & \\
\hline LNS & -0.075 & 0.026 & $-2.9 * * *$ & 0.086 & 0.031 & $2.790 * * *$ \\
\hline NULC & -0.067 & 0.043 & -1.57 & 0.070 & 0.046 & 1.520 \\
\hline NUCRC & 0.048 & 0.041 & 1.17 & -0.061 & 0.049 & -1.250 \\
\hline DFMEXP & 0.005 & 0.008 & 0.6 & -0.020 & 0.009 & $-2.360 * *$ \\
\hline sqrtMLY & 0.209 & 0.031 & $6.63 * * *$ & 0.042 & 0.048 & 0.870 \\
\hline MLCN & -0.237 & 0.033 & $-7.16 * * *$ & & & \\
\hline MEMCOOP & 0.195 & 0.053 & $3.7 * * *$ & -0.178 & 0.069 & $-2.600 * * *$ \\
\hline DSTM & -0.035 & 0.014 & $-2.52 * *$ & 0.028 & 0.016 & $1.710 *$ \\
\hline MRKTEXP & 0.035 & 0.009 & $3.9 * * *$ & & & \\
\hline VLADEXP & & & & 0.005 & 0.003 & 1.380 \\
\hline TLU & 0.004 & 0.066 & 0.05 & 0.045 & 0.073 & 0.620 \\
\hline cons & 0.009 & 0.148 & 0.06 & -0.032 & 0.167 & -0.190 \\
\hline lnsigmal & -1.212 & 0.062 & $-19.510 * * *$ & & & \\
\hline Insigma2 & -1.064 & 0.059 & $-18.120 * * *$ & & & \\
\hline atrho12 & -1.638 & 0.103 & $-15.950 * * *$ & & & \\
\hline sigma1 & 0.297 & 0.018 & $16.090 * * *$ & & & \\
\hline sigma2 & 0.345 & 0.020 & $17.040 * * *$ & & & \\
\hline rho12 & -0.927 & 0.014 & $-64.380 * * *$ & & & \\
\hline \multicolumn{7}{|c|}{ Likelihood ratio test of rho12 $=0: \chi^{2}(1), \mathrm{pr}>\chi^{2} 200.89^{* * *}$} \\
\hline \multicolumn{7}{|c|}{ Log likelihood $\quad-86.470173$} \\
\hline \multicolumn{2}{|c|}{ Number of observation } & \multicolumn{2}{|c|}{200} & & & \\
\hline \multicolumn{2}{|c|}{ Wald $\chi 2(25), \mathrm{pr}>\chi^{2}$} & \multicolumn{2}{|c|}{$499.41 * * *$} & & & \\
\hline
\end{tabular}

The asterisks $* * *$ and $* * *$ represent significance level at $10 \%, 5 \%$ and $1 \%$ respectively.

Source: survey result, 2019

Determinants of raw milk market participation;

Age of household head (AG): The coefficient of household age was found to have indirect relationship with milk supply participation decision and significant at $10 \%$ probability level. The finding was agreed with the results of Bardhan et al, (2012); Berhanu et al., (2014) and Chamboko et al (2017). As age increases by one year, probability of household decision to participate in raw milk marketing decreases by $0.3 \%$. The reason behind might be older farmers had more accumulated capital and assets such as land than younger farmers to support their livelihood.

Family size (FMLSZ): Milk market participation decision was affected by the family size of the household positively and significantly at $10 \%$ significant level. This result is consistent with the result of Benyam et al. (2016) and Emukule et al. (2018). As the family size of increases by one unit of adult equivalent, the participation decision of the household increases by $1.8 \%$. It is known that small scale dairying is labor intensive activity and family is the main source labor for producers. Thus, family sizes translate to labor availability which is expected to increases milk selling decision.

Number of local lactating cows (NULC): Unlike prior expectation number of local lactating cows was negatively and significantly related with milk participation decision at $10 \%$ probability level. The average marginal effect result indicated that increasing lactating cow holding by one local lactating cow, decreases the probability of a household participation decision in raw milk market by $5.7 \%$. This result is contradicted with that of Chamboko et al. (2017) and Benyam et al. (2016). Producers preferred local cows' milk to cross cows' milk for processing and selling butter. Extra local cow holding encourages producers to process and add value instead of selling raw milk.

Dairy farm experience (DFMEXP): Dairy farming experience affected milk market participation decision positively and statistically significant at 5\% significant level. The probability of household participation decision in milk market increases by $1.4 \%$ when dairy farm experience increases by one year. The studies conducted by Zenebe (2014) and Berhanu et al. (2014) contradict this result while the study conducted by Selman et al. (2015) in Nageria found that farm experience and milk maker participation have direct relationship. Experience in dairy farming may develop farmers' production skill and knowledge which in-turn increase productivity. Large volumes of milk push producers to sell milk. 
Volume of milk size (sqrtMLY): As hypothesized prior, the total milk yield size produced per day affected the raw milk market participation decision and intensity positively and significantly at $1 \%$ significant level. One litter increase in volume raw milk size increases the raw milk market participation decision and intensity by $4.7 \%$ and $4.4 \%$ respectively. Producers did not want to pay cost for small size milk delivering. They preferred to consume rather than selling.

Land size (LNS): Land holding size was associated negatively with milk market participation. Milk market participation level of the household was affected by the land size holding negatively and significantly at $1 \%$ significant level. When household land holding size increases by one hectare, the participation level in raw milk supply decreases by $7.5 \%$. The finding coincides with the findings of Berhanu et al. (2104) and Bardhan et al. (2012) Emukule et al. (2018). Land size might attract formers for crop production.

Milk consumption of the household (MLCN): As prior expectation, household milk consumption affected raw milk market participation negatively and significantly at $1 \%$ significant level. The average marginal effect result shows that one litter increase in milk consumption decreases the probability of milk participation by $22 \%$ while the level of participation decrease by $23.7 \%$. Studies conducted by Karna (2015) and Ali (2017) found negative relationship with milk market participation.

Membership cooperative (MEMCOOP): As expected in hypothesis, dairy cooperatives are working for members; empower them by decreasing transaction costs of members which encouraging them to supply raw milk. Thus, membership in dairy cooperative influenced raw milk participation decision and intensity positively and statistically significant at $1 \%$ significant level. The probit result of average marginal effect indicated that being membership increases the probability of household participation in milk market by $12.6 \%$. Similarly being membership in dairy cooperative increases the level of raw milk supply participation by $19.5 \%$. The result is consistent with Phon and Yamaji (2016) and Kumar (2018).

Milk market experience (MRKTEXP): As prior hypothesis experience of milk market affected milk participation decision and intensity positively and statistically significant at $1 \%$ significant level. When milk producer's market experience increases by one year, level of raw milk supply participation increases by $3.5 \%$. Studies conducted by Kumar (2010); Sigei et al. (2013); and Mbitsemunda and Karangwa (2018) showed that market experience had positive relationship with milk market participation.

Distance of market (DSTM): The distance of market affected then milk supply participation decision and intensity negatively and statistically significant at $5 \%$ significant level. One km increases in market distance decreases likelihood of household participation in milk market by $2 \%$ whereas intensity of value of milk market participation decreases by $3.5 \%$. This result is consistent with Omiti et al. (2009), D. Bardhan et al. (2012); Zenebe (2014) and Benyam et al. (2016).

Determinant of value addition participation;

Land size (LNS): It contrary to prior expectation, this variable had positive and significant influence on value addition participation at 1\% significant level. The finding contradicts with the finding of Ali (2017). The reason might be farmers intended to crop production when they have large land size which in-turn leads to small volume of milk. Low volume of per day made farmers to collect milk, process, produce and sell butter. The average marginal effect of bivariate probit implies that keeping other explanatory variables constant, an increase in household land size by one hectare results $10.5 \%$ increase in value addition participation decision. The bivariate Tobit result indicates ceteris paribus, an increase in land size by one hectare increases the value addition participation intensity by $8.6 \%$.

Dairy farm experience (DFMEXP): As prior expectation, dairy farm experience has negative and significant influence on both value addition participation decision and intensity at 5\% probability level. This finding coincides with Karna (2015). The probit result indicates that keeping other explanatory variables constant, one year increase farmer's diary experience decreases the farmer's likelihood to add value to milk by $1.9 \%$. Similarly, the tobit model results shows that keeping other explanatory variables constant, an increase in dairying experience by one year, results $2 \%$ decrease in value addition participation intensity. Rational behind is that dairying experience increases milk volume which in-turn initiates farmers to sell fluid milk rather than selling processed products.

Membership in dairy cooperative (MEMBCOOP): As prior expectation, membership in dairy cooperative affected likelihood of household value addition participation negatively and significantly at $10 \%$ significant level. Similarly, this variable affected value addition participation intensity positively and significantly at $1 \%$ significant level. This depicts that being a membership of dairy cooperative increase the likelihood and intensity of supplying milk to milk collection center; which decreases the volume of milk to be processed at farm level. The finding coincides with the findings of Ali (2017) and Tsega et al. (2017). This implies that ceteris paribus, being membership in dairy cooperative decreases the likelihood of the household to add value to milk by $11.8 \%$. Similarly, keeping other independent variables constant, being membership in dairy cooperative decreases the household's value addition participation intensity by $17.8 \%$.

Value addition experience (VLADEXP): As prior expectation, value addition experience of the household 
affected value addition participation decision positively and significant at 5\% significant level. This variable has positive relationship with value addition participation intensity but not statistically significant. The positive relationship indicates that the more value addition experience, the more skill of processing milk products and more knowledge about customer preference. Those milk producers who are skilled in value addition and have market knowledge could have higher likelihood of value addition participation decision. The finding coincides to the finding of Tijani (2018). This indicates that one year increase of value addition experience results $1.3 \%$ increases of likelihood of households to participate in milk value addition.

Distance of dairy product market (DSTM): Distance of dairy product market has positive and significant influence on value addition participation intensity at $10 \%$ probability level whereas it is associated positively and non-significantly with value addition participation decision. The positive and significant association between two variables revealed that as a household distant from the nearest dairy market, the more milk could be processed at farm level and the products could be delivered to market. This finding coincides with the finding of Tadele et al. (2014) but contradict with finding of Embaye (2015). The model result indicates that one km far from dairy product market increases the household's value addition participation intensity by $2.8 \%$. Rational behind is that farmers are more benefited by adding value to milk, instead selling fluid milk daily to distant market.

\section{SUMMARY, CONCLUSION AND RECOMMENDATIONS}

\subsection{Summary and Conclusions}

The study was conducted with the objective of analyzing determinants of dairy market participation in North Mecha woreda. The specific objectives were; to analyze the determinants of milk producers' milk supply participation decision and level of participation ; to analyze the determinants of milk producers' value addition participation decision and level of participation. Both formal and informal surveys and market visits were carried out during June 2019 up to end of July 2019.

Primary data were collected from 200 sampled producer households that were randomly selected from purposively selected kebles. Beside formal survey, rapid market appraisal (RMA), focus group discussion, and key informants interview were carried out to dig out qualitative data and triangulate formal survey result. The survey data were analyzed using descriptive statistics, inferential statistics and, econometric tool which was bivariate probit- bivariate tobit model with help of STATA 14 software. The main findings of the study are summarized as follows.

Out of the total sampled households $46 \%$ and $62 \%$ of them were participating in raw milk marketing and value addition respectively while the mean raw milk market and value addition participation intensity of sample household was $32.1 \%$ and $39.3 \%$ respectively. Of the total marketed milk $37 \%$ of milk was delivered to national markets. Small scale milk producers who account more than $75 \%$ managed their dairy cows in inseparable house. The main source of feed for dairy cows were hay, concentrate and crop residue and the feeding practices was stall feeding system. AI and bull services were the main breeding systems undertaken by producers to improve their cow productivity. Under small holder milk producers' management local and cross cow productivity per day was $2.2 \pm 1.1$ and $5.8 \pm 2.44$ liters. Butter, ghee and metata-ayib are major milk products processed and sold by smallholder farmers.

The bivariate probit model indicated that age of the household, number of local lactating cows, distance of milk market and household daily milk consumption were found to have negative and significant influence on raw milk supply participation decision of the households. On the contrary, family size, dairy farm experience, daily milk size, and membership of cooperative were found to have positive and significance effect on raw milk supply participation decision of households. Land size and value addition experience were found to have positive and significant influence on value addition participation decision of the households. On the other hand dairy farm experience and membership in dairy cooperatives were found to have negative and significant influence on value addition participation decision of the households.

The bivariate Tobit model indicated land size, household daily milk consumption, and distance of market were found to have negative and significant impact on raw milk supply participation intensity of the household. Milk volume per day, membership of dairy cooperatives and market experience were found to have positive and significant influence on milk supply participation intensity of the household. Land size and distance of market were found to have positive and significance influence on value addition participation intensity of the household. On the contrary, dairy farm experience and cooperative membership were found to have negative and significant influence on value addition participation intensity of the household.

Recommendations

Based on the findings, the study recommends the following interventions and policy implications that are assumed to mitigate the existing market participation problems. Supportive services, credit and saving services, veterinary services system should to be considered to increases dairy production development. Old aged household heads should be educated thorough extension services so as to increase the household dairy farming experience and then the probability of milk supply participation decision. Family size is the source of labor for 
dairy marketing implies that stakeholders should intervene or promote labor saving technologies and infrastructure to increases the probability of household head milk supply participation. The policy implication for negative relationship of number of local lactating cows holding and milk market participation is efforts such as improving dairy cow breed and upgrading milk production potential of local cows need to be done to increase the volume of milk yield per day per household. Membership in dairy cooperatives, distance of milk market, and land size of the household and milk market experience are important variables for milk market participation decision and intensity. It is recommended that the government need to increase market access by increasing number of dairy cooperatives, and improving road and infrastructures in the area.

The econometric model results showed that land size, value addition experience, and distance to dairy market had positive relationship with value addition participation. The implication is household head has low access to raw milk market. This suggests that that investing on roads and market infrastructure enable farmers to realize several milk products market alternatives. In addition, offering processing equipment who are far from raw milk marketing are important. On the other hand, cross dairy farm experience and membership in dairy cooperatives are negatively related to value addition participation. This is due to the household head had more cross dairy cows which are preferable by producers to sell raw milk instead of adding value to milk. This study suggests there should be dairy cow breed based mechanisms and interventions in urban and per-uban areas. Livestock extension services and researches need to be intervened on value addition techniques, equipment, and upgrading, in particular relatively small scale milk producers.

\section{REFERENCES}

Aleme Asresie, Zelalem Yilma, Eyassu Seifu, Lemma Zemedu, Mitiku Eshetu, and Mohammed Kurtu. 2018. Handling, Processing, Utilization and Marketing of Ayib (Ethiopian Traditional Cottage Cheese) Varieties Produced in Selected Areas of Eastern Gojjam, Northwestern Highlands of Ethiopia. Open J. Anim. Sci. 8:51-73. https://doi.org/10.4236/ojas.2018.81005

Alganesh Tola and Yetenayet Bekele Tola. 2017. Traditional butter and ghee production, processing and handling in Ethiopia: A review. African Journal of Food Science, 11(4):95-105.

Ali Tegegne. 2017. Value chain analysis of milk : the case of Dessie Zuria district, South Wollo zone, Northern Ethiopia.

Amemiya, T. 1979. The Estimation of a Simultaneous-Equation Tobit Model. Int. Econ. Rev.20: 169. https://doi.org/10.2307/2526423.

Azage Tegegne, Berhanu Gebremedhin, Dirk Hoekstra, Berhanu Belay and Yoseph Mekasha. 2013. Smallholder dairy production and marketing systems in Ethiopia: IPMS experiences. and opportunities for marketoriented development. IPMS (Improving Productivity and Market Success) of Ethiopian Farmers Project Working Paper 31. Nairobi: ILRI.

Baltagi, B.H.2008. Econometrics. $4^{\text {th }}$ edition. Springer. Syracuse University, USA.

Barrett, C.B., 2008. Smallholder market participation: Concepts and evidence from eastern and southern Africa. Food policy, 33(4), pp.299-317.

Bayan, B. and Deka, R.P., 2018. Crossbred Cattle Adoption and Market Participation Behaviour of Smallholder Dairy Farmers in Assam. International journal of livestock research. DOI:10.5455/ijlr.20171122051450

Bedilu Demissie. 2014. An Analysis of Camel and Cow Milk Marketing Chain amongst Pastorals and AgroPastorals in Gursum and Babile Districts. J. Econ. Sustain. Dev. 5: 129-139.

Behnke, R.H. and Fitaweke Metaferia. 2011. The contribution of livestock to the Ethiopian economy-Part II. Working paper.37.

Benyam Tadesse, Zekarias Shumeta, and Taye Tolemariam.2017. Determinants of milk value addition by farm households in Jimma Zone of Southwestern Ethiopia. education, 3(2).

Benyam Tadesse, Zekarias Shumeta, Taye Tolemariam . 2016. Determinants of dairy farmers' market participation in the major dairy producing towns of Jimma Zone of Southwest Ethiopia. Food Science and Quality Management, 52, pp.66-75.

Berhanu Gebremedhin and Moti Jaleta. 2012 Market Orientation and Market Participation of Smallholders in Ethiopia: Implications for Commercial Transformation, International Livestock Research Institute (ILRI), Addis Ababa, Ethiopia.

Berhanu Gebremedhin, Azage Tegegne, Dirk Hoekstra, Samson Jemaneh, Kaleb Shiferaw, Aklilu Bogale and Yasin Getahun. 2014. Developing the butter value chain in Ethiopia. LIVES Working Paper 1. Nairobi, Kenya: International Livestock Research Institute.

Berhanu kuma, 2012. Determinants of dairy products market participation and market outlet choices in Wolaita zone, Ethiopia. Haramaya university,Haramya, Ethiopia.

Berhanu Kuma,, Baker D.,Kindie Getnet and Belay Kassa ,2014.Factors affecting milk marketing participation and volume of supply in Ethiopia. Asian Journal of rural development. DOI:10.3923/ajrd.2013.

Betela Beyene, Endrias Geta and Amsalu Mitiku. 2017. Determinants of Producers Participation Decision and 
Level of Participation on Milk Value Addition at Farm Level: In Case of Esssera Woreda Dawuro Zone,Southern Ethiopia. J. Econ. Sustain. Dev. 8: 12-22.

Bingi, S. and Tondel, F. 2015. Recent developments in the dairy sector in Eastern Africa Towards a regional policy framework for value chain development: Recent developments in the dairy sector in Eastern Africa. Brief note No. 78.

Brandsma, W., Dawit Mengistu, Binyam Kassa, Mahlet Yohannes and Lee, J. 2013. The Major Ethiopian Milksheds: An assessment of development potential. Wageningen.

Chagwiza, C., Muradian, R. and Ruben, R., 2016. Cooperative membership and dairy performance among smallholders in Ethiopia. Food Policy, 59, pp.165-173.

Chamboko, T., Mwakiwa, E., and Mugabe, P.H. 2017. Determinants of milk market participation and volume of sales to milk collection centres of the smallholder dairy value chain in Zimbabwe. J. Agric. Sci. 9: 156-167. https://doi.org/10.5539/jas.v9n10p156.

Chawla, A., Chawla, N., Pant, Y. and Kandhari, P. 2009. Milk and dairy products in Indiaproduction, consumption and exports. Hindustan Studies and Services Limited, Bhopal, India.

Coltrain, D., Barton, D. and Boland, M., 2000. Value added: opportunities and strategies. Kansas State University, USA.

Corrieu G. and Béal C. 2016. Yogurt: The Product and its Manufacture. The Encyclopedia of Food and Health vol. 5, pp. 617-624. Oxford: Academic Press.

Cotei, C. and Farhat, J., 2011. An application of the two-stage Bivariate Probit-Tobit model to corporate financing decisions. Review of Quantitative Finance and Accounting, 37(3), pp.363-380.

Cragg, J.G. 1971. Some statistical models for limited dependent variables with application to the demand for durable goods. Econometrica, 39(5): 829.

CSA (Central Statistical Agency). 2011. Ethiopia Agricultural Sample Survey 2010/11 (2003 E.C.) Volume II, Report on Livestock and Livestock Characteristics (Private Peasant Holdings)," Statistical Bulletin 505, Federal Democratic Republic of Ethiopia, Central Statistical Agency.

CSA (Central Statistical Agency). 2017. Livestock and Livestock Characteristics (Private Peasant Holdings). Addis Ababa, Ethiopia.

Embaye Kidanu Kindeya .2015. Commercialization through Market Participation: Analysis of Factors Determining Butter Market Participation and Level of Supply, Tigray Region, Ethiopia. Journal of Economics and Sustainable Development.6(11).

Emmanuel Ntirenganya . 2016. Rwanda's dairy exports generated over Rwf9bn in 2016. The new times. Available : https://www.newtimes.co.rw/section/read/206188.

Emukule, J.I. Kipsat, M.J., Wambui, C.C. 2018. Determinants of households ${ }^{e e}$ market participation around community milk cooling plants, western Kenya. J. Agric. Sci. 10: 204. https://doi.org/10.5539/jas.v10n3p204.

Eyassu Siefu and Asaminew Tassew. 2014. Small-scale milk processing, utilization and marketing of traditional dairy products in Bahir Dar Zuria and Mecha districts, Northwestern Ethiopia. J. Food Technol. Res. 1:122-132. https://doi.org/10.18488/journal.58/2014.1.2/58.2.122.132.

Fakoya, E.O., Agbonlahor, M.U., Dipeolu, A.O. 2007. Attitude of women farmers towards sustainable land management practices in south-western Nigeria. World J. Agric. Sci. 3: 536-542.

FAO ( Food and Agriculture Organization). 2012. Designing and implementing livestock value chain studies - A practical aid for Highly Pathogenic and Emerging Disease (HPED) control. FAO Animal Production and Health Guidelines (No. 10). Rome.

FAO (Food and Agriculture Organization) and ILRI (International Livestock Research Institute). 2016. Smallholder dairy methodology, Draft Methodology for quantification of GHG Emission Reductions from Improved Management in Smallholder Dairy production Systems using a Standardized Baseline.

FAO (Food and Agriculture Organization) and NZAGGRC (New Zealand Agricultural Greenhouse Gas Research Centre). 2017. Supporting low emissions development in the Ethiopian dairy cattle sector reducing enteric methane for food security and livelihoods. Rome. $34 \mathrm{pp}$.

FAO (Food and Agriculture Organization). 2014. FAO Statistical Year Book, Africa Food and Agriculture, Second. ed., Accra. www.fao.org/publications. E-ISBN 978-92-5-108166-2 (PDF).

FAO (Food and Agriculture Organization). 1993 marketing systems evaluation: www.fao.org/wairdocs/ilri/x5547e/x5547ela.htm.

FAO (Food and Agriculture Organization). 2011. Dairy development in kenya, by H.G. Muriuki. Rome,Italy.

FAO (Food and Agriculture Organization). 2014. FAO Statistical Year Book 2014 Africa. Food and Agriculture, 2nd Edition. FAORAF and ESS, Accra.

FAO (Food and Agriculture Organization). 2017. Gender assessment of dairy value chains: evidence from Ethiopia by Herego E. Rome, Italy.39. 
FCA. 2016. Basic data of primary cooperatives in Ethiopia; http://www.fca.gov.et/\#

Frew Kassa and Getinet Asefa. 2013. Market Opportunities for Value Added Milk and Meat Products. Ethiopian Institute of Agricultural Research (EIAR),AddisAbeba Ethiopia

Getachew Felleke, Medhin Woldearegay and Getnet Haile.2009. Ethiopia Inventory of Dairy Policy - SNV Ethiopia.

Getnet Hail.2009. The impact of global economic crisis on lower developing countries ; A case study : the dairy sector in Ethiopia . Vienna International Centre, Austria.

Gezu Tadesse and Zelalem Yilma. 2018. Dairy Trade in Ethiopia: Current Scenario and Way Forward-Review. Journal of Dairy \& Veterinary Sciences (JDVS). 8 (1).DOI:10.19080/JDVS.2018.08.555728.

Greene, W. H., 2012. Econometric Analysis International edition. $7^{\text {th }}$ Edition. Pearson Educations. New York.

Gujarati, D., 2003. Basic Econometrics. $4^{\text {th }}$ Edition. Library of congress, Gary Burke. Singapura: McGrawHill. ISBN:978-0-07-233542-2.

Habtemariam Kassa, Gibbon,D. and Bharat P. 2002. Livestock Improve Household Food Security and Sustainability of Ethiopian Small Farms, Journal of Sustainable Agriculture, 21(2): 73-93. DOI: 10.1300/J064v21n02_07.

Heckman, J.J. 1979. Sample selection bias as a specification error. Econometrica: Journal of the econometric society, 153-161.

Jagwe, J.N. 2013.. The impact of transaction costs on the participation of smallholder farmers and intermediaries in the banana markets of Burundi, Democratic Republic of Congo and Rwanda (Doctoral dissertation, University of Pretoria).

Jeffrey M. Wooldridge.2012. Introductory Econometrics. A Modern Approach. $5^{\text {th }}$ Edition. Michigan State University, USA

Karna, S.K. 2015. Determinants of decision to participate in value addition to milk: Level of value addition and decision to choose milk market access. New Man Int. J. Multi Discip. Stud. 2: 112-124.

Kohler, H.P. and Rodgers, J.L., 1999. DF-like analyses of binary, ordered, and censored variables using probit and tobit approaches. Behavior Genetics, 29(4), pp.221-232.

Kubanychbekova, B., 2013. Time for children: Parents' time allocation in Spain. Shonkwiler, J.S. and Harris, T.R., 1996. Rural retail business thresholds and interdependencies. Journal of Regional Science, 36(4), pp.617-630.

Kumar, A., 2010. Milk marketing chains in Bihar: Implications for dairy farmers and traders. Agricultural Economics research review, 23(347-2016-16945), pp.469-478.

Kumar, A., Saroj, S., Joshi, P.K. and Takeshima, H., 2018. Does cooperative membership improve household welfare? Evidence from a panel data analysis of smallholder dairy farmers in Bihar, India. Food Policy, 75(C), pp.24-36.

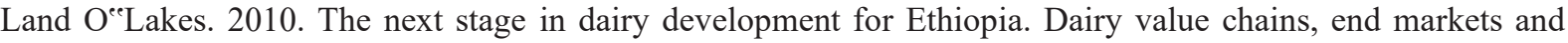
food Security. Cooperative Agreement 663-A-00-05-00431-00. Addis Abeba, Ethiopia.

Leeper, T.J., 2017. Interpreting regression results using average marginal effects with R's margins. Available at the comprehensive R Archive Network (CRAN).

LMD (Livestock Market Development). 2013. Value Chain Analyis for Ethiopia. Addis Ababa,Ethiopia.

Luoga, W., Kurwijila, L.R., Nyange, D. and Ryoba, R., 2007. Determinants of access and participation of smallholder farmers in dairy input and output markets in Tanzania case study of Rungwe district. Tanzania Journal of Agricultural Sciences, 8(1).

Mafa Chipeta, Bezabih Emana, and Demese Chanyalew. 2015. Ethiopiaees Agriculture Sector Policy and Investment Framework (2010-2020), External Mid-term Review. Management Institute and Strategy Management Department, ESSEC, Nepal.

Mbitsemunda, J.P.K. and Karangwa, A., 2017. Analysis of factors influencing market participation of smallholder bean farmers in Nyanza district of Southern Province, Rwanda. J Agric Sci, 9, pp.99-111.

Mebrate Getabalew, Tewodros Alemneh and Dawit Akeberegn . 2019. Dairy Production in Ethiopia-Existing Scenario and Constraints. Biomedical Journal of Scientific \& Technical Research, 16(5), pp.12304-12309.

Mmbando, F.E., Wale, E.Z. and Baiyegunhi, L.J., 2017. The welfare impacts of market channel choice by smallholder farmers in Tanzania. Development in Practice, 27(7), pp.981-993.

Ngore, P.M., 2010. Evaluation of Factors Influencing Value Addition by Butchery Agribusinesses in Igembe North District, Kenya (No. 634-2016-41478).

Nutz,N. and Sievers,M. 2015. Rough guide to value chain development: a short guide for development practitioners, government and private sector initiatives /; International Labour Office,ILO, Geneva. ISBN: 9789221296560; 9789221296577 (web, pdf)

Omiti, J.M., Otieno, D.J., Nyanamba, T.O. and McCullough, E.B. 2009. Factors influencing the intensity of market participation by smallholder farmers: A case study of rural and peri-urban areas of Kenya. African Journal of Agricultural and Resource Economics, 3(311-2016-5509), pp.57-82. 
Phon, D. and Yamaji, E., 2016. Impact of Smallholder Agricultural Cooperatives on Market Participation of Vegetable Farmers in Cambodia: A Case Study of Svay Rieng Agro-Products Cooperative. International Journal of Environmental and Rural Development, 7(1), pp.167-172.

Poluha, R.G. 2016. Strategic Importance of the Supply Chain. In The Quintessence of Supply Chain Management, Springer, Berlin, Heidelberg. pp. 9-54.

Poole, N. (2017) Smallholder Agriculture and Market Participation, Rugby, UK: Practical Action Publishing, http://dx.doi.org/10.3362/9781780449401

Rademaker, C.J., Bebe, B.O., van der Lee, J., Kilelu, C. and Tonui, C., 2016. Sustainable growth of the Kenyan dairy sector: a quick scan of robustness, reliability and resilience (No. 979). Wageningen University \& Research, Wageningen Livestock Research.

Rahman, S. and Chima, C.D., 2016. Determinants of food crop diversity and profitability in southeastern Nigeria: a multivariate tobit approach. Agriculture, 6(2), p.14.

Salman, K.K., Ogunniyi AI, Adeniran TM, Rufai, AM and Obisesan OO. 2015. Market participation among smallholder dairy farmers in Oyo State, Nigeria.

Shapiro, B.I., Gebru, G., Desta, S., Negassa, A., Negussie, K., Aboset, G. and Mechal, H., 2015. Ethiopia livestock master plan: Roadmaps for growth and transformation.

Shapiro,B.I, Getachew Gebru, Solomon Desta, Asfaw Negassa, Kidus Negussie, Gezahegn Aboset and Henok Mecha.2015. Ethiopia livestock master plan Roadmaps for growth and transformation, a contribution to the Growth and Transformation plan II (2015-220), ILRI project Report. Nairobi,Kenya.

Shewangzaw Addisu, Ahmed Muhammed and Nunu Haile, 2016. Handling, Processing and Utilization of Milk and Its Products in Gondar Town, Ethiopia. J. Life Sci. Biomed. 6, 120-126.

Sigei, G., Bett, H. and Kibet, L., 2014. Determinants of market participation among small-scale pineapple farmers in Kericho County, Kenya.

SNV (Netherlands Development Organization). 2008. Dairy Investment Opportunities in Ethiopia. Addis Ababa,Ethiopia

Sodini, I., Morin, P., Olabi, A. and Jiménez-Flores, R., 2006. Compositional and functional properties of buttermilk: a comparison between sweet, sour, and whey buttermilk. Journal of Dairy Science, 89(2), pp.525-536.

Solomon Gizaw , Megersa Abera, Melku Muluye, Hoekstra D., Berhanu Gebremedhin , and Azage Tegegne.2016. Smallholder dairy farming systems in the highlands of Ethiopia: System-specific constraints and intervention. LIVES Working Paper 23 (No.23) Nairobi, Kenya: International Livestock Research Institute (ILRI).

Spring. 2013. Financial Econometrics: Limited dependent variables and sample selection.

Springer-Heinze, A., 2018. ValueLinks 2.0. Manual on Sustainable Value Chain Development. Eschborn, Germany.

Tadele Mamo, Tewodros Tefera, and Noreen Byre. 2014. Factors influencing urban and peri-urban dairy producers' participation in milk value addition and volume of milk value added in Welmera Woreda, West Shewa Zone of Oromia Regional State, Ethiopia. International Journal of livestock production, 5(9), pp.165-172.

TAP Consultancy services, 2016. Value Chain Study on "Dairy Industry in Ethiopia ”,Final report.Addis Ababa,Ethiopia.

Tesfaye Amene. 2017. Challenges and opportunities of milk, meat and live animal marketing in Ethiopia: A review. International Journal of Livestock Production, 8(11), pp.180-186. http://www.academicjournals.org/IJLP. DOI: 10.5897/IJLP2017.0400

The RVO (Rijksdienst voor Ondernemend Nederland ).2016. Report for: Rijksdienst voor Ondernemend Nederland. Dairy quick scan Sudan.

Tijani, S.A., 2018. Determinants of market participation among small scale shea butter processors in Kwara State, Nigeria. Tanzania Journal of Agricultural Sciences, 17(1).

Tobin, J., 1958. Estimation of Relationships for Limited Dependent Variables. Econometrica 26, 24. https://doi.org/10.2307/1907382.

Tsega Lemma, Tewodros Tefera, and Sintayehu Yigrem.2017. Determinants of participation in milk value addition by dairy producers in Asella Milk-Shed, Ethiopia. Journal of Science \& Development, 4, p.1.

Webber, C.M. and Labaste, P., 2010. Building competitiveness in Africa's agriculture: a guide to value chain concepts and applications. The World Bank.

Yitaye Alemayehu Ayenew, Wurzinger,M., Azage Tegegne and Zollitsch,W. 2009. Handling, processing and marketing of milk in the North western Ethiopian highlands. Livestock Research for Rural Development, 21(7), p.97. Retrieved 2019, from http://www.lrrd.org/lrrd21/7/ayen21097.htm

Yoo, S.H., 2005. Analyzing household bottled water and water purifier expenditures: simultaneous equation bivariate Tobit model. Applied Economics Letters, 12(5), pp.297-301. 
https://doi.org/10.1080/1350485042000293121

Zelalem Yilma, Loiseau, G. and Faye,B., 2015. Behavior of Salmonella Typhimurium DT104 during the Manufacturing of Ergo and Ayib, Ethiopian Traditional Fermented Milk Products. Research and Reviews: Journal of Food and Dairy Technology, 3(3), pp.1-8.

Zenebe, M. 2014. Market chain Analysis of dairy products: In the case of Gozamen woreda, East gojjam zone, Ethiopia. Haramaya University

Zhang, H., Kuuluvainen, J., Yang, H., Xie, Y. and Liu, C., 2017. The effect of off-farm employment on forestland transfers in China: A simultaneous-equation Tobit model estimation. Sustainability, 9(9), p.1645. 